\title{
Przestrzenne zróżnicowanie wykorzystania technologii informacyjno-komunikacyjnych w przedsiębiorstwach przemysłowych w Polsce
}

W ostatnich latach wiele uwagi poświęcono procesowi budowania gospodarki opartej na wiedzy (GOW), którego istotnym elementem jest tworzenie i wykorzystanie innowacji. Ich kreowanie oraz praktyczne wykorzystanie ma wpływ na kształtowanie konkurencyjności przedsiębiorstw, regionów i państw. Wśród innowacji, których znaczenie gwałtownie rośnie znajdują się technologie informacyjno-komunikacyjne. Zainteresowanie tą grupą technologii wiąże się z postępem w zakresie możliwości gromadzenia, przetwarzania i rozpowszechniania przez nie rosnącej liczby danych w krótkim czasie. Dzięki temu możliwa jest szeroka i o wysokiej dynamice przestrzenna dyfuzja wiedzy.

Według definicji stosowanej przez GUS [1999: 126], technologiami informacyjno-komunikacyjnymi (technologiami informacyjnymi) są „technologie związane ze zbieraniem, przechowywaniem, przetwarzaniem, przesyłaniem i prezentacją informacji (tj. tekstów, obrazów, dźwięków). Obejmują w szczególności technologie komputerowe - sprzęt i oprogramowanie".

Badanie zróżnicowania przestrzennego występowania i wykorzystania technologii informacyjnych nie jest zadaniem łatwym. Wynika to z małej dostępności mierników w przekrojach terytorialnych. Głównym źródłem informacji w tym zakresie jest prowadzona przez Główny Urząd Statystyczny sprawozdawczość o innowacjach w przemyśle. Badania te prowadzone są drogą ankietową i obejmują średnie i duże przedsiębiorstwa przemysłowe zatrudniające ponad 49 osób. Cennym źródłem danych dotyczących rozwoju technologii informacyjno-komunikacyjnych oraz sposobów ich wykorzystania są również raporty Instytutu Logistyki i Magazynowania w Poznaniu.

Można wyróżnić trzy cele badawcze niniejszego artykułu. Pierwszy z nich obejmuje analizę zróżnicowania regionalnego występowania i wykorzystania technologii informacyjnych w przedsiębiorstwach przemysłowych w Polsce. Problematyka ta obejmuje również zaangażowanie przedsiębiorstw w gospodarkę elektroniczną. Drugi z celów dotyczy określenia związku między wykorzystaniem Internetu a rozwojem gospodarczym w układzie województw Polski. Ostatni jest próbą określenia barier społeczno-gospodarczych w dostępie oraz wykorzystaniu technologii informacyjnych. 


\section{PodstaWy TEORETYCZNE ANALIZY PRZESTRZENNO-EKONOMICZNEJ WYKORZYSTANIA TECHNOLOGII INFORMACYJNYCH}

Właściwa infrastruktura informacyjna oraz proces zarządzania wiedzą pochodzącą z różnych źródeł są niezbędnymi elementami prowadzącymi do tworzenia nowych, innowacyjnych produktów, procesów i usług [Widmaier 2000]. Wytwarzanie ich sprzyja rozwojowi gospodarczemu i wzrostowi konkurencyjności państw. Znaczenie innowacji w tych procesach podkreślał m.in. J.A. Schumpeter [1960], który źródeł ich powstawania poszukiwał w nierównowadze ekonomicznej. Zauważył, że dzięki trwającej ciągle konkurencji między przedsiębiorcami i wprowadzaniu nowych rozwiązań w zakresie środków produkcji następuje tzw. twórcza destrukcja systemu gospodarczego. Zjawisko to sprzyja poszukiwaniu nowych, innowacyjnych rozwiązań i pobudzaniu przedsiębiorczości, co w efekcie przyczynia się do wzrostu gospodarczego.

Rozwinięciem schumpeterowskiej teorii w odniesieniu do technologii informacyjnych jest koncepcja długich fal i cykli ewolucji przemysłu Kondratiewa. Autor koncepcji podkreśla rolę doniosłej innowacji powodującej wielkoskalową zmianę technologii. Zjawisko to określane jest jako zmiana paradygmatu techniczno-ekonomicznego, który generuje łańcuch innowacji w systemie produkcji i organizacji działalności gospodarczej. W cyklu ewolucji przemysłu Kondratiew wyróżnił cztery długie fale, z których każda, trwająca ok. 50 lat, zapoczątkowana została doniosłą innowacją. Pojawienie się pierwszej z fal, przypadające na koniec XVIII wieku, wiąże się z pozyskaniem energii pochodzącej z pary wodnej i rozwojem przemysłu tekstylnego. Kształtowanie się następnych trzech fal zapoczątkowane jest

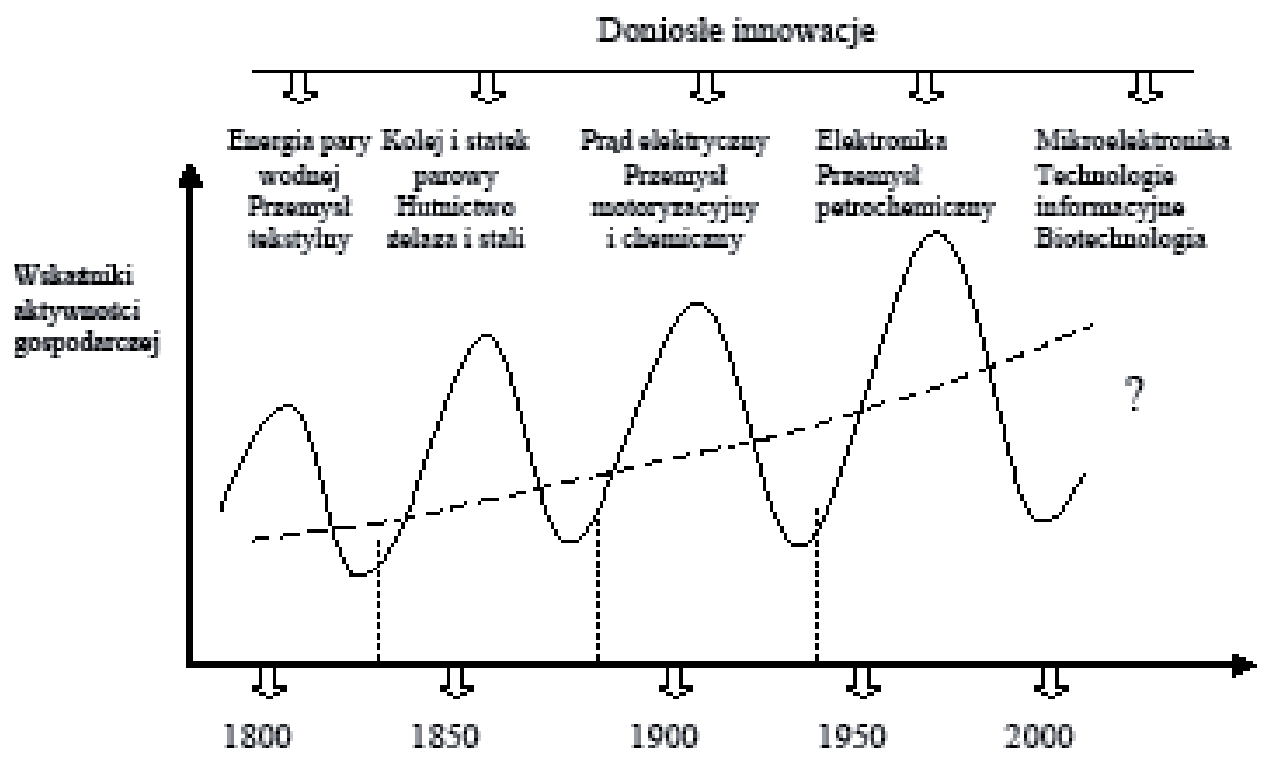

Ryc. 1. Długie fale i cykle ewolucji przemysłu Kondratiewa 
m.in. przez wprowadzenie środków transportu zasilanych energią pochodzącą z pary wodnej (statek oraz kolej parowa), a następnie przez powszechne zastosowanie elektryczności oraz elektroniki. Każda z fal dzieli się na 4 fazy: ożywienia gospodarczego po wprowadzeniu doniosłej innowacji, koniunktury, recesji oraz depresji. Nie został całkowicie określony przebieg piątej długiej fali ewolucji przemysłu. Przyjmuje się jednak, że jej powstanie wiąże się ze zmianą paradygmatu techniczno-ekonomicznego i wzrostem znaczenia informacji oraz technologii informacyjnych (Stryjakiewicz 1999). L. Schätzl (1993) zauważa, że falom ewolucji przemysłu towarzyszy rosnący poziom aktywności gospodarczej, mimo występowania różnych faz rozwoju (ryc. 1). Można zatem przyjąć, że wprowadzenie i powszechne wykorzystanie technologii informacyjnych w Polsce wiązać się będzie ze wzrostem aktywności gospodarczej.

\section{CHARAKTERYSTYKA WYBRANYCH TECHNOLOGII INFORMACYJNYCH}

Przez ostatnie sto lat urządzenia wykorzystywane w procesach produkcyjnych zmieniały się od prostych, ręcznie sterowanych do zaawansowanych systemów, opartych na technologiach informacyjnych. Obecnie stosowane technologie wykorzystywane są w celu wymiany informacji zarówno wewnątrz przedsiębiorstwa, jak i między nim a otoczeniem. W pierwszym przypadku jest to regulacja, wyznaczanie i utrzymywanie wymaganej jakości procesu produkcyjnego. W drugim jest to wymiana informacji między przedsiębiorstwami (B2B - business-to-business) oraz między przedsiębiorstwem a indywidualnym klientem (B2C - business-to-consumer). Relacje tego typu charakteryzują gospodarkę elektroniczną (e-commerce) ${ }^{*}$ i stanowią coraz częściej istotny element prowadzonej działalności gospodarczej przedsiębiorstw [Szyszka, Śliwczyński 2004]. Początki handlu elektronicznego określanego od 1997 r. terminem gospodarki elektronicznej (e-commerce), sięgają lat sześćdziesiątych, kiedy to duże koncerny i korporacje przemysłowe rozpoczęły tworzenie firmowych sieci informatycznych służących do wymiany informacji z ich partnerami handlowymi (www.mg.gov.pl 2004). Technologie informacyjne pozwalają także na pozyskiwanie oraz przekazywanie informacji niezwiązanych z prowadzoną działalnością gospodarczą. Dzięki temu istnieje dyfuzja szeroko rozumianej wiedzy. W tabeli 1 zawarto charakterystykę wybranych technologii informacyjnych oraz możliwości ich wykorzystania.

Tabela 1. Wybrane technologie informacyjne stosowane w przedsiębiorstwach

\begin{tabular}{|l|l|}
\hline \multicolumn{1}{|c|}{ Wybrana technologia } & \multicolumn{1}{c|}{ Charakterystyka } \\
\hline $\begin{array}{l}\text { Komputery do sterowania } \\
\text { i regulacji procesami tech- } \\
\text { nologicznymi }\end{array}$ & $\begin{array}{l}\text { Jednostki stosowane do przygotowania dokumentacji technologicznej, } \\
\text { sterowania, regulacji i kontroli przebiegu procesu technologicznego. }\end{array}$ \\
\hline $\begin{array}{l}\text { Linie produkcyjne stero- } \\
\text { wane komputerem }\end{array}$ & $\begin{array}{l}\text { Linia technologiczna automatyczna, przy czym przebieg operacji na } \\
\text { przedmiocie jest kompleksowo zaprogramowany i sterowany kom- } \\
\text { puterem łącznie z samoczynnym ustaleniem optymalnych warunków } \\
\text { przebiegu operacji i wymaganych parametrów. }\end{array}$ \\
\hline
\end{tabular}

* Według Światowej Organizacji Handlu (WTO) przez e-commerce należy rozumieć produkcję, reklamę, sprzedaż i dystrybucję produktów poprzez sieci teleinformatyczne. Instrumentami gospodarki elektronicznej są: telefon, telefax, telewizja, Elektroniczna Wymiana Danych (EDI) oraz Internet (www.parp.gov.pl 2004). 


\begin{tabular}{|l|l|}
\hline System CAD/CAM & Projektowanie i wytwarzanie wspomagane komputerowo. \\
\hline $\begin{array}{l}\text { Lokalna sieć komputerowa } \\
\text { (LAN) }\end{array}$ & $\begin{array}{l}\text { Łączy między sobą blisko znajdujących się użytkowników. } \\
\text { Umożliwia wymianę zbiorów informacji (plików) i komunikatorów } \\
\text { między użytkownikami oraz wspólne użytkowanie (współdzielonych) } \\
\text { zasobów. }\end{array}$ \\
\hline $\begin{array}{l}\text { System elektronicznej wy- } \\
\text { miany danych (EDI) }\end{array}$ & $\begin{array}{l}\text { Elektroniczna wymiana informacji pomiędzy firmami przy użyciu } \\
\text { sieci. Jest to jedna z form gospodarki elektronicznej, istniejąca już od } \\
\text { kilkudziesięciu lat i obejmująca zautomatyzowane transakcje między } \\
\text { przedsiębiorstwami (B2B) bez interwencji człowieka. Kodowanie } \\
\text { danych odbywa się za pomocą międzynarodowego standardu zwanego } \\
\text { EDIFACT. }\end{array}$ \\
\hline Internet & $\begin{array}{l}\text { Rozległa sieć o ogólnoświatowym zasięgu - zbiór setek tysięcy lokal- } \\
\text { nych sieci komputerowych i indywidualnych komputerów używają- } \\
\text { cych protokołu komunikacyjnego TCP/IP. Protokołem komunikacyj- } \\
\text { nym jest zbiór formalnych reguł i konwencji szczegółowo określają- } \\
\text { cych mechanizm wymiany informacji między stacjami połączonymi } \\
\text { medium transmisyjnym, zwykle jest to kabel sieciowy. }\end{array}$ \\
\hline
\end{tabular}

Źródło: Nauka i technika w Polsce w 2001 r., GUS, Warszawa 2002, s. 126

\section{WYSTĘPOWANIE TECHNOLOGII INFORMACYJNYCH}

Jednym z przejawów kształtowania się piątej fali ewolucji przemysłu w Polsce był wzrost liczby posiadanych przez przedsiębiorstwa technologii informacyjnych (tab. 2).

Tabela 2. Technologie informacyjne w przedsiębiorstwach przemysłowych w Polsce w latach 2001-2002

\begin{tabular}{|l|r|r|r|c|c|}
\hline \multirow{2}{*}{ Technologia } & \multicolumn{2}{|c|}{2001} & \multicolumn{2}{c|}{2002} & \multirow{2}{*}{\begin{tabular}{c} 
Dynamika \\
\cline { 2 - 5 }
\end{tabular}} \\
\cline { 2 - 5 } & $\begin{array}{c}\text { Liczba } \\
\text { przedsię- } \\
\text { biorstw }\end{array}$ & $\%$ & $\begin{array}{c}\text { Liczba } \\
\text { przedsię- } \\
\text { biorstw }\end{array}$ & $\%$ & 200100) \\
\hline $\begin{array}{l}\text { Komputery do sterowania i regulacji procesami } \\
\text { technologicznymi }\end{array}$ & 16988 & $\mathrm{X}$ & 18626 & $\mathrm{X}$ & 112,2 \\
\hline Linie produkcyjne sterowane komputerem & 5014 & 57,9 & 5848 & 68,9 & 119,1 \\
\hline Przedsiębiorstwa z systemami CAD/CAM & 1374 & 15,9 & 1780 & 21,0 & 132,2 \\
\hline $\begin{array}{l}\text { Przedsiębiorstwa posiadające lokalne sieci kompu- } \\
\text { terowe (LAN) }\end{array}$ & 4956 & 57,2 & 5508 & 64,9 & 113,4 \\
\hline $\begin{array}{l}\text { Przedsiębiorstwa z systemami elektronicznej wy- } \\
\text { miany danych (EDI) }\end{array}$ & 1172 & 13,5 & 1638 & 19,3 & 142,7 \\
\hline
\end{tabular}

Źródło: Nauka i technika w Polsce w 2001 r., Nauka i technika w Polsce w 2002 r. GUS, Warszawa 2002, 2004

Zjawisko to występowało nawet w krótkim okresie - roku. Jednak jego dynamika była zróżnicowana w zależności od rodzaju technologii. Biorąc pod uwagę wskaźniki związane $\mathrm{z}$ technologiami stosowanymi $\mathrm{w}$ przedsiębiorstwach przemysłowych od drugiej połowy lat 80 . (komputery do sterowania i regulacji procesami technologicznymi), charak- 
teryzowały się one zarówno małym natężeniem występowania (ok. 2 komputerów na 1 przedsiębiorstwo), jak i niską dynamiką wzrostu (ok. 12\% rocznie). Biorąc pod uwagę, że badaniami objęto przedsiębiorstwa średnie i duże, są to niskie wartości. Najnowocześniejsze rozwiązania w zakresie wykorzystania komputerów w procesach projektowania (CAD) i wytwarzania produktów (CAM) oraz elektronicznej wymiany danych (EDI) charakteryzują się znacznie wyższą dynamiką (odpowiednio ok. 43\% i ponad 32\%). Wynika to z dużych możliwości zastosowania ich w podnoszeniu jakości produkcji i szybkiej wymianie informacji o towarach. Jednak ze względu na dużą innowacyjność tych rozwiązań wykorzystywane są one tylko w nielicznych przedsiębiorstwach posiadających pracowników o wysokich kwalifikacjach (CAD/CAM - 21\%, EDI - 19,3\% przedsiębiorstw).

\section{WYKORZYSTANIE TECHNOLOGII INFORMACYJNYCH}

Wzrost poziomu infrastruktury informacyjnej w postaci urządzeń nie jest jedynym czynnikiem, który wpływa na kształtowanie się piątej fali ewolucji przemysłu. Istotne znaczenie odgrywa bowiem umiejętne wykorzystanie technologii, m.in. w postaci Internetu. Sieć o ogólnoświatowym zasięgu umożliwia występowanie dyfuzji informacji, która jest elementem kształtowania się fali ewolucji.

Biorąc pod uwagę lata 1999-2002 zaobserwowano duży wzrost wykorzystania tej formy komunikacji elektronicznej. W 2002 r. ponad 86\% przedsiębiorstw przemysłowych korzystało z Internetu, podczas gdy trzy lata wcześniej tylko nieco ponad połowa. Są to jednak wartości średnie dla całej Polski, nie ukazujące różnic regionalnych. Aby je poznać, należy przeprowadzić analizę w układzie województw.

Wśród przedsiębiorstw przemysłowych korzystających z Internetu w 2002 r. najwyższy odsetek występował w województwach południowej Polski (powyżej 91\%) oraz w województwie podlaskim $(95,3 \%)$ i zachodniopomorskim $(92,3 \%$; ryc. 2). Warto zwrócić uwagę, że w przypadku dwóch ostatnich województw nastąpił znaczny wzrost wartości wskaźnika w stosunku do 1999 r., kiedy zajmowały one ostatnie miejsca. W przypadku podlaskiego zjawisko to można thumaczyć rosnącymi wydatkami na maszyny i urządzenia (w tym komputery osobiste), które stanowiły $69 \%$ nakładów na działalność innowacyjną [Olechnicka 2004]. Dzięki temu wzrosła możliwość dostępu do Internetu. Natomiast w 2002 r. najniższy odsetek przedsiębiorstw korzystających z Internetu występował w pasie województw zachodniej, centralnej i wschodniej Polski (wielkopolskim - 76,5\%, mazowieckim - 81,6\%, łódzkim $-82,3 \%$ i lubelskim - 84,5\%,). Małe wykorzystanie Internetu w województwach lubelskim i łódzkim wynika ze struktury przemysłu, który oparty jest na tradycyjnych, często niedoinwestowanych gałęziach. Wydaje się, że właśnie przedsiębiorstwa należące do tych gałęzi mogłyby liczyć na większy rozwój dzięki wprowadzeniu i wykorzystaniu Internetu. Niestety, skromne środki finansowe ograniczają możliwość zakupu omawianych technologii pozwalających na wzrost konkurencyjności. Zauważyć należy, że województwa wielkopolskie i mazowieckie, w których znajdują się duże aglomeracje miejskie także charakteryzują się niskim wskaźnikiem dostępu do Internetu wśród omawianej grupy przedsiębiorstw. Świadczy to o dużych dysproporcjach między głównymi ośrodkami miejskimi a ich otoczeniem. Korzyści aglomeracji, wiążące się z występowaniem przedsiębiorstw stosujących innowacyjne technologie informacyjne, nie rekompensują różnic między miastem a obszarem wiejskim. 

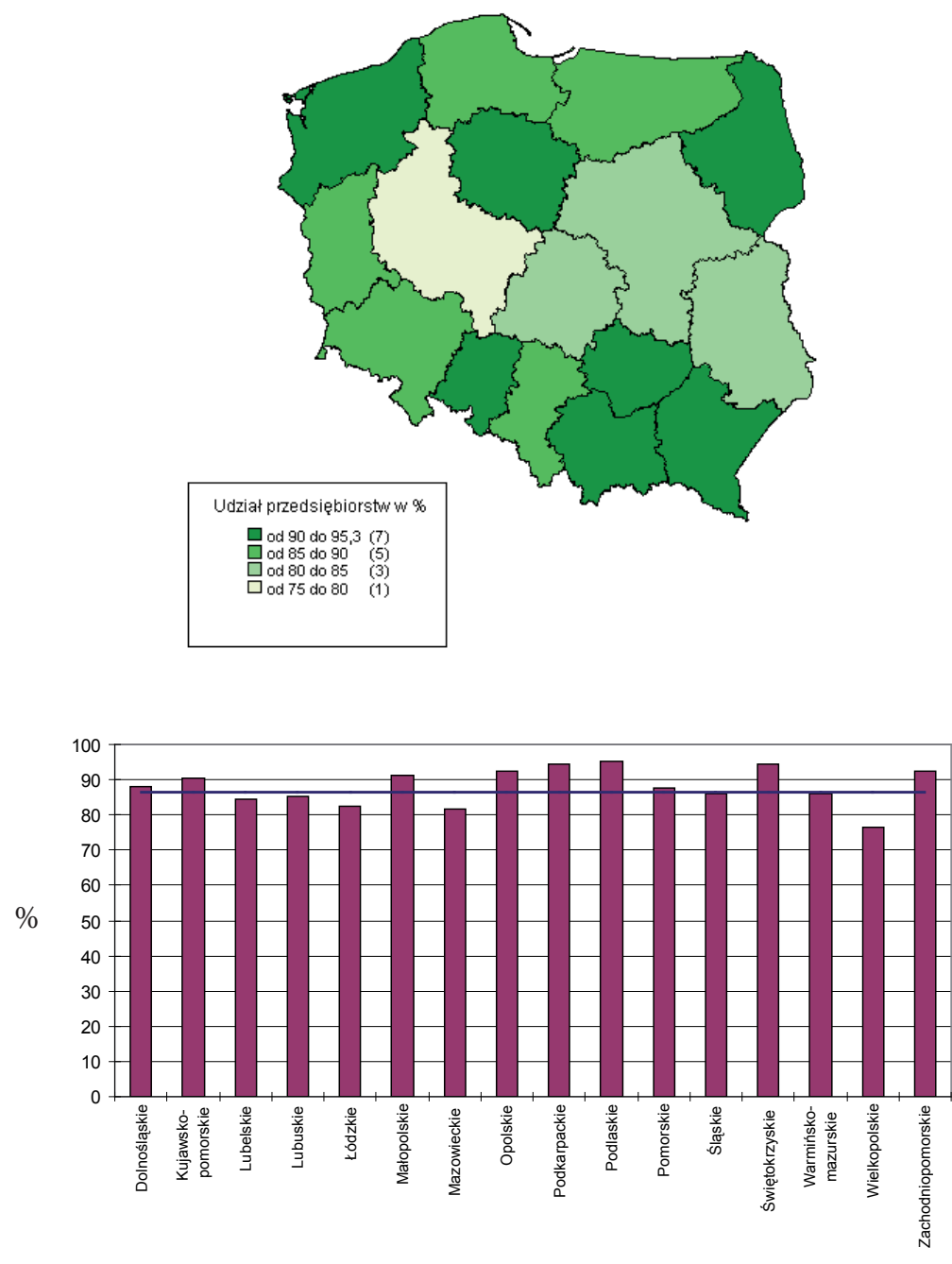

poziom zjawiska —

Ryc. 2. Odsetek przedsiębiorstw przemysłowych korzystających z Internetu w 2002 r.

Źródło: Nauka i technika w Polsce w 2002 r. GUS, Warszawa 2004

W województwach, w których odnotowano większy dostęp do Internetu wśród przedsiębiorstw przemysłowych istnieje szeroki zakres możliwości jego wykorzystania m.in. dzięki prowadzeniu gospodarki elektronicznej. Jednym z pierwszych kroków do zaistnienia podmiotu gospodarczego w sieci jest posiadanie własnej strony internetowej WWW. Rosnące znaczenie tej formy informacji o prowadzonej działalności gospodarczej przejawia się w szybkim wzroście odsetka przedsiębiorstw przemysłowych posiadających strony WWW (z 54,1\% w 2001 r. do 62\% w 2002 r.). Zróżnicowanie przestrzenne wartości wskaźnika w układzie województw było zbliżone do dostępu przedsiębiorstw do Internetu. Najniższe war- 
tości występowały w pasie województw w środkowej części Polski, od zachodniej do wschodniej granicy (lubuskie - 51,7\%, wielkopolskie 54,5\%, mazowieckie - 58,5\% i lubelskie - 55,1\%; ryc. 3). Natomiast najwyższe wartości wskaźnika występowały w województwach południowej Polski oraz w województwie podlaskim $(71,7 \%)$ i kujawsko-pomorskim $(68,9 \%)$.
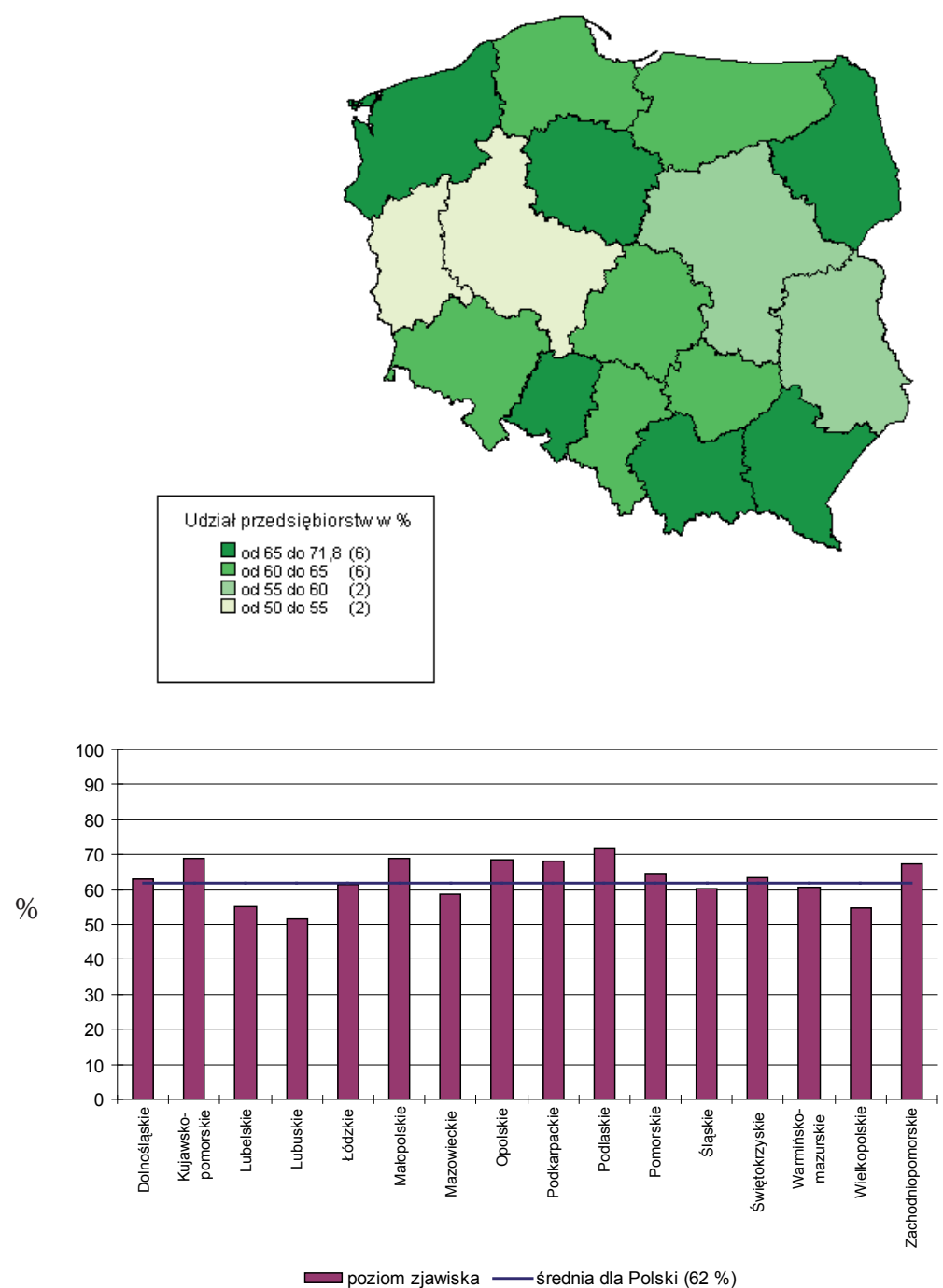

Ryc. 3. Odsetek przedsiębiorstw przemysłowych posiadających własne strony WWW w $2002 \mathrm{r}$.

\section{Źródło: Nauka i technika w Polsce w 2002 r. GUS, Warszawa, 2004}

Wśród przedsiębiorstw posiadających dostęp do Internetu można wydzielić dwie grupy przedsiębiorstw przemysłowych, które prowadziły gospodarkę elektroniczną. Do pierwszej z nich należały te, które wykorzystując posiadane przez siebie strony internetowe WWW prowadziły marketing i udostępniały informacje o swoich produktach (tab. 3). Natomiast 
w drugiej grupie znalazły się przedsiębiorstwa, które były odbiorcami informacji zawartych na stronach internetowych. Pierwsza kategoria obejmowała głównie przedsiębiorstwa z województw południowej Polski, które charakteryzowały się najwyższą dostępnością do Internetu. Natomiast drugą grupę stanowiła większość przedsiębiorstw z województw przygranicznych zachodniej Polski, które dokonywały głównie zakupu wyrobów i usług. Wydaje się, że czynnikiem sprzyjającym prowadzeniu tej działalności jest przyjmowanie wzorca postępowania zza sąsiadującej granicy. W Niemczech bowiem gospodarka elektroniczna stanowi istotny element działalności przedsiębiorstw [Henschel 2002]. Ponadto dzięki wykorzystaniu Internetu istniała możliwość dokonywania zakupów u niemieckich partnerów handlowych.

Tabela 3. Regionalne zróżnicowanie wykorzystania Internetu w przedsiębiorstwach przemysłowych w Polsce w $2002 \mathrm{r}$.

\begin{tabular}{|l|c|c|c|c|}
\hline \multirow{2}{*}{ Województwa } & \multicolumn{3}{|c|}{ Formy wykorzystania Internetu w przedsiębiorstwach } \\
\cline { 2 - 5 } & $\begin{array}{c}\text { Monitorowanie } \\
\text { rynku }\end{array}$ & $\begin{array}{c}\text { Prowadzenie } \\
\text { marketingu }\end{array}$ & $\begin{array}{c}\text { Udostęnianie } \\
\text { informacji }\end{array}$ & $\begin{array}{c}\text { Dokonywanie zakupu } \\
\text { towarów i usług }\end{array}$ \\
\hline Polska & $\mathbf{4 7 , 6}$ & $\mathbf{4 2 , 6}$ & $\mathbf{4 3 , 5}$ & $\mathbf{1 3 , 6}$ \\
dolnoślaskie & 47,6 & 44,4 & 41,9 & 11,8 \\
kujawsko-pomorskie & 48,8 & 44,8 & 44,6 & 16,9 \\
lubelskie & 44,2 & 36,5 & 35,3 & 13,3 \\
lubuskie & 40,7 & 38,0 & 35,0 & 18,6 \\
łódzkie & 47,0 & 42,7 & 44,1 & 11,8 \\
małopolskie & 52,4 & 48,3 & 52,2 & 8,0 \\
mazowieckie & 47,4 & 41,6 & 42,1 & 14,7 \\
opolskie & 54,7 & 48,4 & 47,1 & 17,3 \\
podkarpackie & 53,3 & 49,8 & 53,8 & 14,7 \\
podlaskie & 57,4 & 50,2 & 54,3 & 12,8 \\
pomorskie & 48,9 & 44,4 & 44,6 & 16,3 \\
śląskie & 47,9 & 41,1 & 42,1 & 12,4 \\
świętokrzyskie & 58,9 & 50,1 & 50,1 & 13,5 \\
warmińsko-mazurskie & 39,5 & 37,9 & 41,4 & 15,3 \\
wielkopolskie & 39,1 & 36,0 & 37,6 & 12,2 \\
zachodniopomorskie & 52,2 & 42,7 & 43,3 & 17,8 \\
\hline
\end{tabular}

Źródło: Nauka i technika w Polsce w 2002 r. GUS, Warszawa 2004

Należy zauważyć, że do obu omawianych grup przedsiębiorstw przemysłowych prowadzących gospodarkę elektroniczną należą te, które znajdują się w województwach po- 
łudniowej Polski. Jedną z przyczyn występowania takiego zjawiska jest lokalizacja na tych terenach średnich i dużych zagranicznych przedsiębiorstw przemysłowych. Prowadzenie przez nie gospodarki elektronicznej może świadczyć o przenoszeniu wzorców postępowania z państw pochodzenia, gdzie takie formy prowadzenia działalności są częściej wykorzystywane. Prowadzone przez GUS badania pokazują, że przedsiębiorstwa tego typu stanowią większość w niewielkiej grupie ankietowanych podmiotów, zlokalizowanych w województwach południowej Polski. Mają zatem duży wpływ na wynik badań. Próba zbadania wykorzystania technologii informacyjno-komunikacyjnych w przedsiębiorstwach małych, poniżej 49 osób mogłaby dostarczyć nieco innych wyników.

Mimo dużego zróżnicowania przestrzennego występowania technologii informacyjnych w przedsiębiorstwach przemysłowych w układzie województw Polski, można zauważyć zainteresowanie różnymi sposobami ich wykorzystania. Internet, jako jedna z form komunikacji, umożliwia $36 \%$ przedsiębiorstw przemysłowych posiadających dostęp do niego prowadzenie gospodarki elektronicznej. Jest to dziewięciokrotnie więcej w stosunku do zaledwie 4\% z ogółu przedsiębiorstw posiadających dostęp do sieci w Polsce, które prowadzą taką gospodarkę [Wykorzystanie technologii... 2005]. Wydaje się, że tak jak w przypadku wielu państw świata również w Polsce prowadzenie gospodarki opartej m.in. na elektronicznej formie wymiany informacji pozwoli zarówno przedsiębiorstwom przemysłowym jak i innym rozwijać się szybciej.

\section{WYKORZYSTANIE TECHNOLOGII INFORMACYJNYCH A ROZWÓJ GOSPODARCZY}

Kształtowanie się piątej fali ewolucji przemysłowej zapoczątkowane wprowadzeniem doniosłej innowacji przejawia się we wzmożonej aktywności gospodarczej [Schumpeter 1960; Schätzl 1993]. Mierzalnym obrazem tego zjawiska jest wzrost wartości wskaźników ekonomicznych. W grupie najbardziej podstawowych znajduje się produkt krajowy brutto (PKB) przypadający na 1 mieszkańca. Porównując zmiany jego wartości oraz wskaźnika dostępu do Internetu w latach 1999-2002 można zauważyć wzrost w obu przypadkach, choć o różnej ich dynamice dla całego kraju, jak i województw (ryc. 4). W okresie badanych trzech lat w Polsce PKB na 1 mieszkańca wzrósł o 21\%, natomiast liczba przedsiębiorstw przemysłowych posiadających dostęp do Internetu na 100 przedsiębiorstw wzrosła o $70,7 \%$. W tym samym okresie zróżnicowanie przestrzenne wartości ostatniego ze wskaźników w układzie województw charakteryzowało się znacznymi odchyleniami. W województwach lubelskim, podlaskim, świętokrzyskim i warmińsko-mazurskim nastąpiło prawie podwojenie liczby przedsiębiorstw z dostępem do Internetu (średnio z 43,2 do 91,7 przedsiębiorstw z dostępem do Internetu na 100 przedsiębiorstw). W tym samym czasie dynamika wartości PKB na 1 mieszkańca była znacznie niższa. W województwach podlaskim i lubelskim przekraczała nieznacznie wartość średnią dla kraju (21,3\%), a w województwach świętokrzyskim i warmińsko-mazurskim kształtowała się poniżej niej (odpowiednio 19,36\% i 13,97\%). Prócz niskiej dynamiki wzrostu PKB na 1 mieszkańca w tych województwach wystąpiła także jego najniższa wartość na tle całego kraju (podlaskie - 14727 PLN, lubelskie - 13614 PLN, świętokrzyskie - 14843 PLN, warmińsko-mazurskie - 14065 PLN). Pozostałe województwa mimo wyższego poziomu rozwoju gospodarczego od omawianych, nie charakteryzowały się tak wysoką dynamiką wzrostu dostępności Internetu w przedsiębiorstwach przemysłowych. 


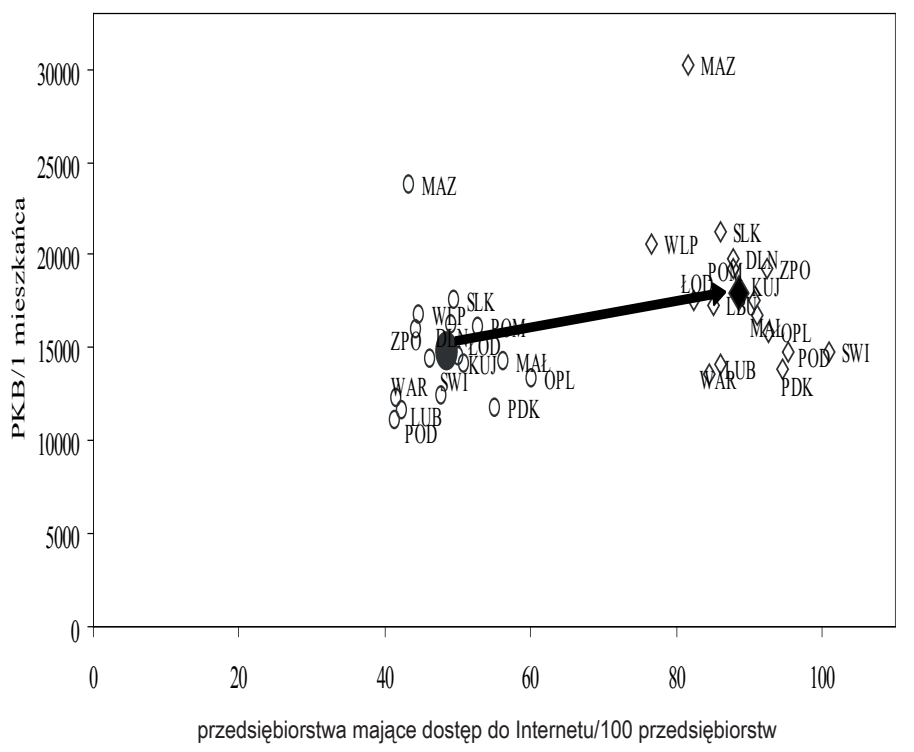

0 $1999 \mathrm{r} . \quad \diamond 2002 \mathrm{r} . \quad \bullet$ Wartości średnie dla 1999 r. $\quad$ Wartoścíśrednie dla $2002 \mathrm{r}$.

\begin{tabular}{|l|c|c|}
\hline \multicolumn{1}{|c|}{ Województwo } & $\begin{array}{c}\text { Przedsiębiorstwa posiadające dostęp } \\
\text { do Internetu/100 przedsiębiorstw } \\
(1999=100)\end{array}$ & $\begin{array}{c}\text { PKB/1 mieszkańca } \\
(1999=100)\end{array}$ \\
\hline Polska & 170,66 & 121,03 \\
\hline dolnośląskie (DLN) & 160,21 & 121,42 \\
\hline kujawsko-Pomorskie (KUJ) & 163,40 & 124,38 \\
\hline lubelskie (LUB) & 195,24 & 122,52 \\
\hline lubuskie (LBU) & 165,93 & 119,45 \\
\hline łódzkie (LOD) & 159,08 & 120,96 \\
\hline małopolskie (MAL) & 155,15 & 117,97 \\
\hline mazowieckie (MAZ) & 165,38 & 127,45 \\
\hline opolskie (OPL) & 138,36 & 118,47 \\
\hline podkarpackie (PDK) & 174,21 & 118,70 \\
\hline podlaskie (POD) & 208,99 & 127,18 \\
\hline pomorskie (POM) & 152,04 & 119,73 \\
\hline śląskie (SLK) & 173,18 & 120,73 \\
\hline świętokrzyskie (SWI) & 196,72 & 119,36 \\
\hline warmińsko-mazurskie (WAR) & 192,86 & 113,97 \\
\hline wielkopolskie (WLP) & 159,20 & 123,21 \\
\hline zachodniopomorskie (ZPO) & 170,59 & 121,01 \\
\hline
\end{tabular}

Ryc. 4. Dynamika dostępu do Internetu w przedsiębiorstwach przemysłowych i PKB na 1 mieszkańca w latach 1999-2002

Źródło: opracowanie własne na podstawie Rocznik statystyczny Rzeczpospolitej Polskiej, GUS, Warszawa 2003, Nauka i technika w Polsce w 2002 r. GUS, Warszawa 2004 


\section{BARIERY W DOSTĘPIE I KORZYSTANIU Z TECHNOLOGII INFORMACYJNYCH}

Mimo dużego tempa wzrostu wykorzystania technologii informacyjnych w przedsiębiorstwach przemysłowych w Polsce, wartość wskaźników charakteryzujących je pozostaje poniżej poziomu krajów Unii Europejskiej. Przyczyn występującego zacofania jest wiele. Wśród nich znajdują się głównie opóźnienia wynikłe z okresu gospodarki centralnie planowanej, a także często podejmowane błędne decyzje $\mathrm{z}$ okresu transformacji ustrojowej związane z restrukturyzacją przedsiębiorstw. W celu zwiększenia ich konkurencyjności ograniczano często wydatki również na wprowadzanie innowacji. Raport Instytut Logistyki i Magazynowania w Poznaniu [Szyszka, Śliwczyński 2004] wskazuje, że główną barierą wprowadzania technologii informacyjnych w przedsiębiorstwach, w tym przemysłowych, są uwarunkowania ekonomiczne, polegające na zbyt wysokich kosztach zakupu technologii przy ograniczonych możliwościach finansowych (ryc. 5). Należy jednak zwrócić uwagę, że wydatki na nowoczesne technologie informacyjne w niedługim okresie ulegają zwrotowi. Następuje bowiem ograniczenie nakładów na pracę, a jakość produktów zostaje podniesiona. Dzięki temu przedsiębiorstwo staje się bardziej konkurencyjne [Katz 2000].

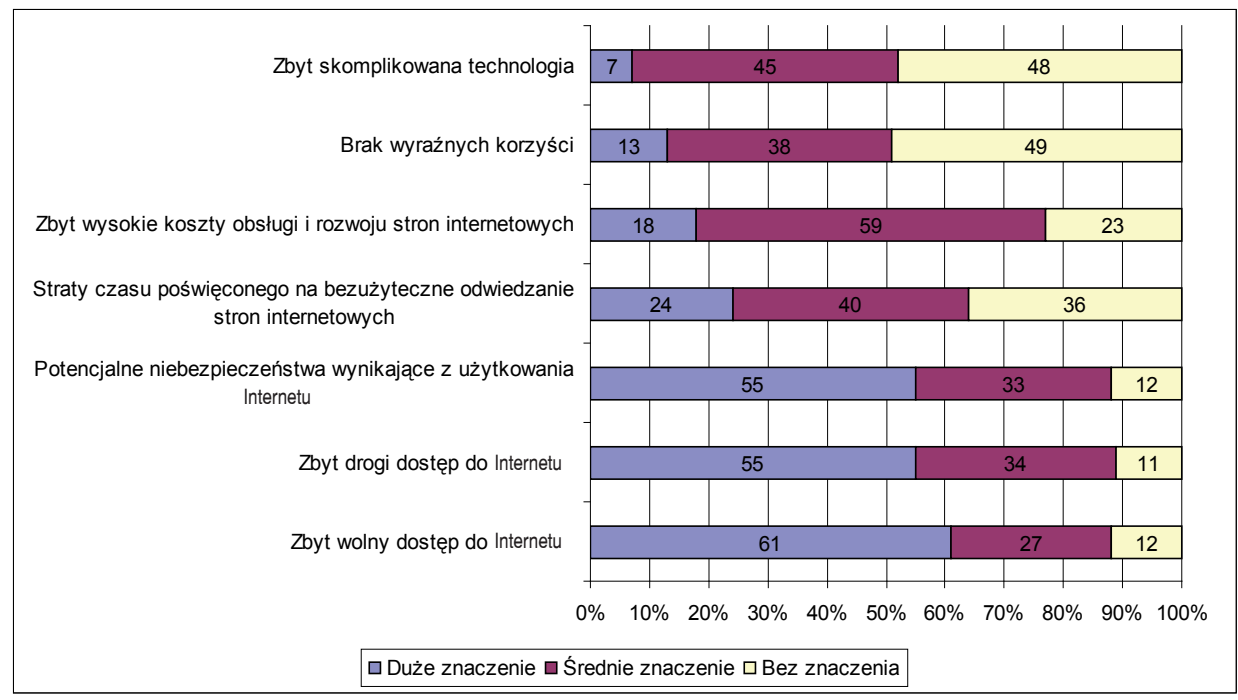

Ryc. 5. Bariery społeczno-ekonomiczne w dostępie do technologii informacyjnych w przedsiębiorstwach w Polsce

Źródło: Elektroniczna gospodarka w Polsce. Raport 2003, ILiM, Poznań 2004

Druga grupę ograniczeń we wprowadzaniu technologii informacyjnych stanowią uwarunkowania społeczne. Należą do nich małe zasoby wiedzy w zakresie korzystania z tych technologii. Wskazują na to wyniki cytowanego powyżej raportu, które mówią o słabych kwalifikacjach pracowników oraz braku ich zasobów na rynku pracy. Wiąże się z tym kolejna $\mathrm{z}$ barier $\mathrm{w}$ postaci zbyt często wprowadzanego na rynek nowego oprogramowania. Jego poznanie i umiejętne wykorzystanie może stanowić problem dla osób nie posiadających właściwych kwalifikacji w zakresie obsługi technologii informacyjnych. 
Wśród barier ograniczających korzystanie z technologii informacyjnych, np. w postaci Internetu, można wyróżnić głównie uwarunkowania zewnętrzne względem przedsiębiorstwa. Wskazuje się na dostarczycieli usług internetowych (ryc. 6), których wini się za niski poziom infrastruktury (słaby transfer danych) oraz drogi dostęp do usługi. Badania wskazują również na niebezpieczeństwa związane z dostępem do Internetu (nieuczciwa konkurencja, wirusy, włamania). Jednak tego typu zagrożenia mogą szybko zostać wyeliminowane, dzięki rozwijającym się technologiom zabezpieczającym.

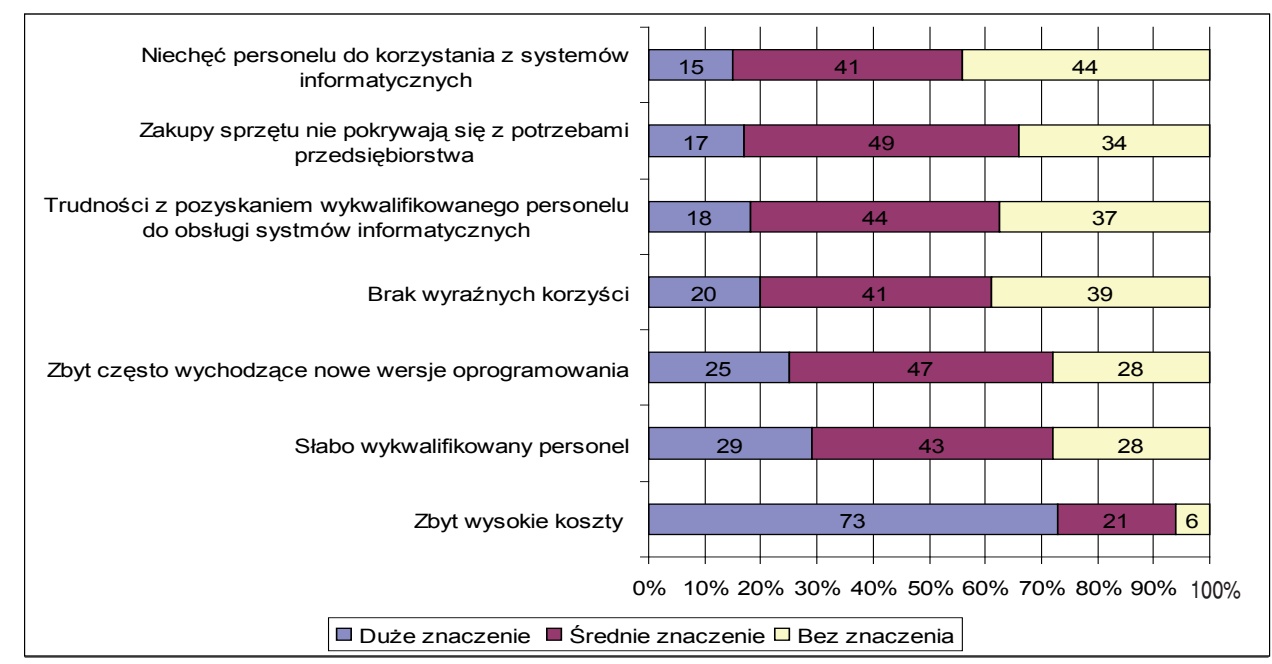

Ryc. 6. Bariery w korzystaniu z Internetu w przedsiębiorstwach w Polsce

Źródło: Elektroniczna gospodarka w Polsce. Raport 2003, ILiM, Poznań 2004

\section{PERSPEKTYWY ROZWOJU WYKORZYSTANIA TECHNOLOGII INFORMACYJNYCH W PRZEDSIĘBIORSTWACH PRZEMYSŁOWYCH W POLSCE}

Przeprowadzona analiza zróżnicowania przestrzennego występowania i wykorzystania technologii informacyjnych w polskich przedsiębiorstwach przemysłowych w układzie województw wskazuje, że w latach 1999-2002 odnotowano różnice w wartościach wskaźników charakteryzujących tę grupę technologii. W regionach charakteryzujących się niższym rozwojem gospodarczym zaobserwowano wysokie tempo wzrostu występowania i wykorzystania omawianych technologii. Szczególnym przypadkiem było województwo podlaskie, gdzie przy jednej z najniższych wartości PKB przypadającego na 1 mieszkańca (14 727 PLN) prawie wszystkie średnie i duże przedsiębiorstwa przemysłowe zatrudniające powyżej 49 osób posiadały dostęp do Internetu (95,3\%). W tym oraz w innych województwach słabiej rozwiniętych gospodarczo, mimo wielu barier, coraz większym zainteresowaniem wśród przedsiębiorców cieszyło się prowadzenie gospodarki elektronicznej. Wydaje się, że dzięki temu możliwa będzie aktywizacja gospodarcza tych regionów. 
W świetle przeprowadzonych badań można stwierdzić, że wiodącą grupą przedsiębiorstw w Polsce, posiadających dostęp do Internetu i prowadzących gospodarkę elektroniczną są przedsiębiorstwa przemysłowe (36\% przedsiębiorstw przemysłowych w stosunku do 4\% ogólnej liczby przedsiębiorstw posiadających dostęp do Internetu; GUS 2005).

Wydaje się, że występujący w omawianym okresie wysoki wzrost występowania i wykorzystania technologii informacyjnych w polskich przedsiębiorstwach może ulegać zwiększeniu w nadchodzących latach. Wiąże się to z nie słabnącym zainteresowaniem omawianymi technologiami wśród przedsiębiorców. Jednym z czynników są względy ekonomiczne. Przedsiębiorcy są bowiem coraz bardziej świadomi racjonalności kosztów ponoszonych w związku ze stosowaniem technologii informacyjnych. Wydatki związane z ich zakupem i korzystaniem w niedługim czasie zostają zwrócone dzięki ograniczeniu kosztów związanych z nakładami na tradycyjnie wykonywaną pracę. Z punktu widzenia ponoszonych kosztów, należy również spodziewać się ograniczenia wydatków związanych z dostępem do sieci internetowej. Wynika to z rosnącej konkurencji wśród dostawców, polegającej na obniżaniu cen usług internetowych.

Dzięki Rozporządzeniu Rady Ministrów z dnia 7 sierpnia 2002 r. w sprawie podpisu elektronicznego (Dz.U. nr 128, poz. 1094) i powołaniu programów rządowych nakierowanych na rozwój gospodarki elektronicznej przewiduje się, że w nadchodzących latach wzrośnie liczba przedsiębiorstw zainteresowanych tą formą prowadzenia działalności. Wykorzystanie systemów komunikacji opartych na elektronicznej wymianie danych (EDI) umożliwi usprawnienie przekazu informacji i wzrost bezpieczeństwa danych zapisanych w postaci elektronicznej [Szyszka, Śliwczyński 2004].

Rozwój innowacji w zakresie technologii informacyjnych jest szansą dla przedsiębiorstw, regionów i państw na wzrost ich konkurencyjności. Ich wykorzystywanie eliminuje ograniczenia w postaci tradycyjnie pojmowanej odległości. Dzięki temu istnieje szansa na rozwój przedsiębiorstw zlokalizowanych na peryferiach, poza aglomeracjami miejskimi.

\section{Literatura}

Henschel S. 2002, Locational Effects of Innovations in information and communication technology on food retailing in Germany, [w:] Technological change and regional development in Europe, red. L. Schätzl, Heidelberg, Physica-Verlag, New York

Katz J.M. 2000, Structural reforms and technological behaviour. The sources and nature of Technological change in Latin America, [w:] The knowledge-based economy. The European challenges of the $21^{\text {st }}$ century, red. A. Kuklinnski, KBN, Warszawa, s. 186-212

Nauka i technika w Polsce w 2001 r., 2002, GUS, Warszawa

Nauka i technika w Polsce w 2002 r., 2004, GUS, Warszawa

Ministerstwo Gospodarki i Pracy, 2004. www.mpips.gov.pl.

Olechnicka A. 2004, Regiony peryferyjne w gospodarce informacyjnej, Scholar, Warszawa

Rocznik statystyczny Rzeczpospolitej Polskiej, 2003, GUS, Warszawa

Rozporządzeniu Rady Ministrów z dnia 7 sierpnia 2002 r. w sprawie podpisu elektronicznego, Dz.U. nr 128, poz. 1094

Polska Agencja Rozwoju Przedsiębiorczości, 2005. www.parp.gov.pl 2004

Schätzl L. 1993, Wirtschaftsgeographie 1. Teorie, Schöningh, Paderborn

Schumpeter J.A. 1960, Teoria rozwoju gospodarczego, PWN, Warszawa

Stryjakiewicz T. 1999, Adaptacja przestrzenna przemystu $w$ Polsce $w$ warunkach transformacji, Wydawnictwo Naukowe UAM, Poznań 
Szyszka G., Śliwczyński B. 2004, Elektroniczna gospodarka w Polsce. Raport 2003, Biblioteka logistyka, Poznań

Wiedmaier B. 2000, Knowledge, innowation systems and knowledge-based economy in Europe, [w:] The knowledge-based economy. The European challenges of the $21^{s t}$ century, red. A. Kukliński, KBN, Warszawa, s. 39-46

Wykorzystanie technologii informacyjno-telekomunikacyjnych $w$ przedsiębiorstwach i gospodarstwach domowych w 2004 r., 2005, GUS, Warszawa

\section{Spatial differences in the use of information-communication technologies in industrial plants in Poland}

In the recent years much attention has been given to the building of a knowledge-based economy (KBE). Of crucial importance in this process is the designing and practical use of innovations. They enhance the competitiveness of enterprises, regions and countries. Among the innovations of rapidly increasing significance are information-communication technologies, which make it possible to accumulate, process and circulate an ever-growing number of data over a short period of time. This allows a widespread and highly dynamic diffusion of knowledge.

The article presents spatial differences among voivodships in Poland in the use of informationcommunication technologies in industrial plants. The analysis is preceded by a theoretical introduction, presenting J.A. Schumpeter's theory of a creative destruction of the economic system as well as Kondratiev's conception of long waves and cycles of industrial evolution. In this way the importance of innovations - including those in information-communication technologies - for economic growth is stressed. By showing differences among voivodships in the use of information-communication technologies, leaders in this field and those lagging behind are identified. A comparison is also made of the dynamics of economic growth of voivodships based on their per capita GDP figures and their use of this group of technologies. The article closes with the description of barriers hindering access to those technologies and their use. The conclusions present prospects of their development. 